\title{
Integrating cultivar resistance and disease warning system to control downy mildew of onion
}

\author{
E. R. Araújo ${ }^{1}$ - R. S. Resende ${ }^{1}$ D. P. Alves ${ }^{1}$ • F. S. Higashikawa ${ }^{1}$ \\ Received: 24 April 2019 / Accepted: 10 December 2019 / Published online: 18 December 2019 \\ (C) Australasian Plant Pathology Society Inc. 2019
}

\begin{abstract}
The management of downy mildew of onion requires frequent applications of protective and systemic fungicides. In order to reduce production costs, we evaluated a control strategy that integrated the use of resistant experimental cultivar and a disease warning system. Regardless of the type of management adopted, the experimental cultivar was always more productive. In turn, management based on the applications of protective fungicide was more effective. Considering only the value of the fungicide and using the resistant experimental cultivar, we had a cost of BRL 3.5 cents $/ \mathrm{kg}$ for management only with Antracol®; BRL 10.7 cents $/ \mathrm{kg}$ for management based on the warning system; and BRL 14.8 cents $/ \mathrm{kg}$ for management only with Ridomil囚 Gold MZ. The integration of different control strategies for downy mildew can bring greater productivity and profitability to farmers.
\end{abstract}

Keywords Allium cepa $\cdot$ Peronospora destructor $\cdot$ Integrated management

Onion (Allium cepa) covered an area of 58,001 ha in the 2017/ 18 crop season in Brazil, resulting in a production of $1,719,412 \mathrm{t}$ (IBGE 2017). The southern region of the country is responsible for $63.69 \%$ of the national production, and it is in this region that downy mildew of onion, caused by Peronospora destructor, is the main foliar disease of the crop.

The management of downy mildew is carried out with weekly applications of fungicides, which in some crop seasons, do not show highly satisfactory control, and represent high costs for the farmers. Considering this scenario, Araújo et al. (2017a, b) proposed a warning system that reduced the number of sprays by maintaining the phytosanitary quality of the crop. Additionally, Alves et al. (2018) conducted screening for downy mildew resistance and found two more resistant experimental cultivars ("Superprecoce - Agroecológica" and "Bola Precoce - Agroecológica"). Thus, this work aimed to integrate these two technologies as a management strategy for downy mildew of onion, in order to make the production process more profitable and sustainable.

The field assay was conducted in 2018 at Epagri/ Experimental Station of Ituporanga, Santa Catarina state, in

E. R. Araújo

edivanioaraujo@epagri.sc.gov.br

1 Epagri/Estação Experimental de Ituporanga, Estrada Geral Lageado Águas Negras, 453, CEP, Ituporanga, SC 88400-000, Brazil the southern region of Brazil. All cultural practices were performed as recommended: soil $\mathrm{pH} \sim 6 ; 100 \mathrm{~kg}$ of N/ha, $80 \mathrm{~kg}$ of $\mathrm{P} / \mathrm{ha}$, and $60 \mathrm{~kg}$ of K/ha (Epagri 2013; Kurtz et al. 2018). The experimental plots were composed of 100 plants (five rows with 20 plants), arranged in a spacing of $0.40 \mathrm{~m}$ (between rows) $\times 0.10 \mathrm{~m}$ (between plants), simulating a density of approximately 250,000 plants per hectare. The experiment was arranged in a completely randomised block design using four replications per treatment, in the factorial design $2 \times 3$ (cultivar $\times$ type of phytosanitary management). Two cultivars were used: an experimental cultivar [called "Bola Precoce Agroecológica", characterised as more resistant to downy mildew by Alves et al. 2018], and the cultivar Empasc 352 - Bola Precoce, characterised as more susceptible. The three types of phytosanitary management were: 1 - spraying with systemic and protective fungicide (Ridomil Gold ${ }^{\circledR}$ MZ, Syngenta) according to the warning system (severe risk) proposed by Araújo et al. (2017a, b), which is available on the Agroconnect platform (http://www.ciram.sc.gov.br/agroconnect). It should be noted that in the week with no severe risk of downy mildew, only one protective fungicide (Antracol@ $700 \mathrm{WP}$, Bayer) was sprayed, since the non-application of any product in the experimental plot could render the control unfeasible due to the climatic conditions of the region, which are extremely favourable to the occurrence of the disease; 2 - spraying with Ridomil Gold ${ }^{\circledR}$ MZ weekly, independently of the warning system; 3 weekly applications of fungicide with protective action (Antracol® 700 WP, Bayer), regardless of the warning system. 
The amount of active ingredient per hectare for all treatments were: $0.1 \mathrm{~kg}$ of metalaxyl-M $+1.6 \mathrm{~kg}$ of mancozeb when Ridomil Gold® MZ was applied; and $2.1 \mathrm{~kg}$ of propineb when Antracol ${ }^{\circledR} 700 \mathrm{WP}$ was applied. The treatments were applied manually using pressure sprayers (SeeSa ${ }^{\circledR}, 2-1$ capacity), corresponding to spray volume of $500 \mathrm{~L}$ per hectare.

Onion seedlings were grown on soil beds (April) and were transplanted to the field approximately 60 days after sowing (during June). Downy mildew occurred due to natural infection, since disease outbreaks are frequent in the region. Sporangia and sporangiophores were incorporated into the work collection of phytopathogenic fungi of Phytosanitary Laboratory at Epagri/EEITU (code EITF 21), according to the preservation technique of freeze-drying (Laviola et al. 2006). Samples of $P$. destructor were also sent to the FLOR herbarium (FLOR 67946) located in Florianópolis, Santa Catarina, Brazil. Disease severity was assessed every 14 days (five evaluations), starting 42 days after transplanting. The severity was rated for each plot using a rating description scale (1-9), which assigns notes to the entire plot (Mohibullah 1991). The values from scale notes of the experimental plots were used to calculate the area under disease progress curve AUDPC (Shaner and Finney 1977). Onion bulbs were harvested from the central rows of each plot, discarding single border rows, 121 days after transplanting. Only bulbs with diameter $\geq 35 \mathrm{~mm}$ were quantified as commercial bulbs.

The data were analysed using ANOVA and, in case of significance of the treatments, means were grouped with Scott-Knott cluster analysis $(p=0.05)$. The software Sisvar v. 5.6 (Ferreira 2011) was used for all analyses.

For the AUDPC variable, a significant difference was observed only for the factor cultivar $(p$ value $=0.0004)$. The factor type of phytosanitary management $(p$ value $=0.6923)$ as well as the interaction between the two factors $(p$ value $=$ 0.8277 ) were not significant. The experimental cultivar presented lower severity than the cultivar Empasc 352 - Bola Precoce, regardless of the type of management adopted (Table 1). In turn, the commercial yield was significantly different for the factor cultivar $(p$ value $=0.0001)$ and for the type of phytosanitary management ( $p$ value $=0.0008)$. However, there was also no significant interaction between these factors $(p$ value $=0.4851)$. The weekly application of Antracol ${ }^{\circledR} 700$ WP resulted in higher yields, both for the more resistant experimental cultivar and for the cultivar Empasc 352 - Bola Precoce. Although there was no significant interaction between the factors, we chose to present Table 1 completely because there is relevant information about the cost of production. Yield values were similar for weekly applications of
Table 1 Area under disease progress curve (AUDPC), commercial yield and production cost in experimental plots according to the cultivar and the type of phytosanitary management adopted, in Santa Catarina state, Brazil, to control downy mildew of onion (Peronospora destructor). A - average values of AUDPC and comercial yield for the factors cultivar and type of phytosanitary management. B - average values of AUDPC and commercial yield in the unfolding of the factor type of phytosanitary management within the factor cultivar, and corresponding cost of production values

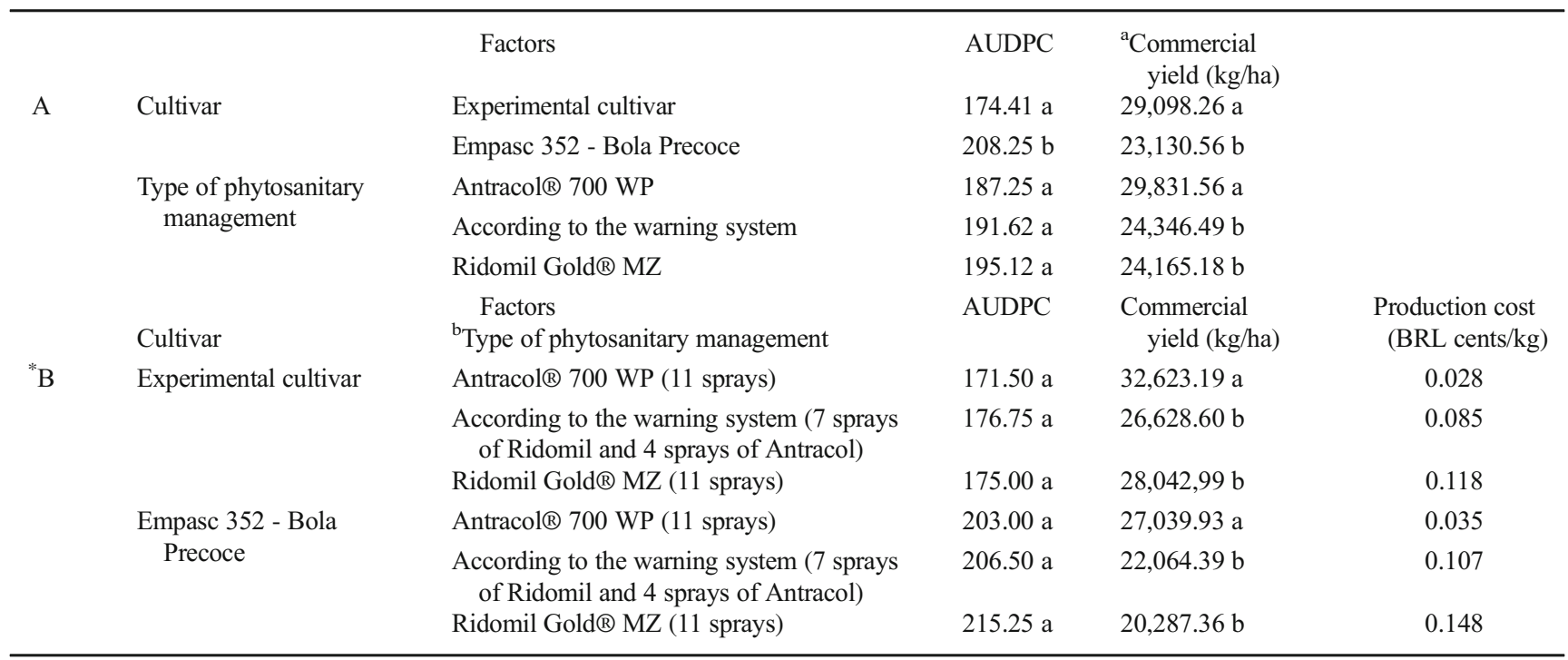

\footnotetext{
${ }^{a}$ Rotten bulbs and bulbs with less than $35 \mathrm{~mm}$ in diameter were not considered for yield quantification

${ }^{\mathrm{b}}$ The amount of active ingredients per hectare using Antracol® was $2.1 \mathrm{~kg}$ of propineb; and using Ridomil Gold® MZ was $0.1 \mathrm{~kg}$ of metalaxyl-M + $1.6 \mathrm{~kg}$ of mancozeb

*Although there was no interaction between the factors cultivar $\times$ type of phytosanitary management, we chose to present the unfolding due to the importance of the values of cost of production

Means in the same column and followed by the same letter did not differ according to Scott-Knott cluster analysis $(p=0.05)$
} 
Ridomil Gold $® \mathrm{MZ}$ and for applications based on the disease warning system. However, there was a reduction of around $36 \%$ in the number of sprays with Ridomil Gold ${ }^{\circledR} \mathrm{MZ}$ in the management based on the warning system (Table 1).

The warning system is intended for applications of fungicides with systemic action, since these are normally more expensive products. In addition, metalaxyl-M (the most commonly used systemic molecule to control downy mildew in the region) presents a high risk of selection of resistant strains (FRAC 2018).

The integration of different control methods increases the chances of better management of plant diseases. This was observed by Didelot et al. (2016) when they integrated more resistant cultivars and the application of fungicides based on climatic parameters to control apple scab (Venturia inaequalis). These authors demonstrated better control efficiency and a delay in disease outbreaks after a five-year study. Warning systems need to be improved and updated routinely. Abuley and Nielsen (2019) integrated potato cultivars with different levels of resistance to early blight (Alternaria solani) into the TOMCAST model and observed that the thresholds of the model could be altered according to susceptibility of the cultivar. In the present study, we tried to integrate a new tool (cultivar less susceptible to downy mildew) to the system developed for the conditions of the state of Santa Catarina, Brazil.

Another issue that should be considered is the reduction in production costs (related to the application of fungicide) caused by the reduction in the number of sprays. The average price for application of the maximum dose of Antracol ${ }^{\circledR} 700$ WP is around BRL 75.00 per hectare, while the approximate cost for application of the maximum dose of Ridomil Gold ${ }^{\circledR}$ MZ is BRL 312.00 per hectare. The fungicide Antracol ${ }^{\circledR} 700$ WP presented an excellent cost-benefit ratio, since it is cheaper and presented the best productivities. However, 2018 had lower rainfall volumes than the local historical average, especially in October (historical average for the month of October $=147$ to $200 \mathrm{~mm}$; volume observed for October $2018=134.4 \mathrm{~mm}$ ). Thus, in rainier years, application of fungicides with only protective action would not be recommended. When we compared the management based on the warning system and the weekly application (farmers routine), we observed, for both cultivars, that the sprays following the warning system presented better cost benefit (Table 1). In addition to the phytosanitary aspect, the cost of production should be considered in works that validate or use plant disease warning systems. Caffi et al. (2012) presented a reduction of expenditure of up to 161 euros/ha/year using an alert system for grapevine powdery mildew (Erysiphe necator) when compared to grower's spray program.

Additional strategies for the chemical control of downy mildew onion are necessary, since there are few molecules with high efficiency in disease control (Wordell Filho et al. 2007). In this scenario, alternative products such as phosphites and acibenzolar-s-methyl have already been unsuccessfully tested
(Araújo et al. 2017a, b). However, given the extremely favourable climatic conditions and the high concentration of onion in the region (approximately 14,000 ha), the integration of control methods seems to be an alternative for the economically viable management of the disease. In addition, we are evaluating different fungicides and will evaluate other possible inducers of resistance (such as methyl jasmonate) in order to find alternatives for the management of downy mildew of onion.

Acknowledgements This work was funded by: Epagri; CNPq (409509/ 2018-3).

\section{References}

Abuley IK, Nielsen BJ (2019) Integrating cultivar resistance into the TOMCAST model to control early blight of potato, caused by Alternaria solani. Crop Protect 117:69-76

Alves DP, Araújo ER, Wamser GH, Gonçalves PAS, Marinho CD, Tomaz RS (2018) Field performance and screening for resistance to Peronospora destructor of 46 onion cultivars in Brazil. Australasian Plant Dis Notes 13:5

Araújo ER, Alves DP, Knoth JR (2017a) Weather-based decision support reduces the fungicide spraying to control onion downy mildew. Crop Protect 92:89-92

Araújo ER, Gonçalves PAS, Alves DP (2017b) Acibenzolar-S-methyl, and potassium and calcium phosphites are not effective to control downy mildew of onion in Brazil. Australasian Plant Dis Notes 12:30

Caffi T, Legler SE, Rossi V, Bugiani R (2012) Evaluation of a warning system for early-season control of grapevine powdery mildew. Plant Dis 96:104-110

Didelot F, Caffier V, Orain G, Lemarquand A (2016) Sustainable management of scab control through the integration of apple resistant cultivars in a low-fungicide input system. Agric Ecosys Environ $217: 41-48$

Epagri (2013) Sistema de produção para a cebola: Santa Catarina (4 Revisão). Florianópolis 106 (Epagri. Sistema de Produção, 46)

Ferreira DF (2011) Sisvar: a computer statistical analysis system. Ciênc Agrotec 35:1039-1042

FRAC (2018) FRAC Code List@ 2018: Fungicides sorted by mode of action (including FRAC Code numbering).http://www.frac.info/ docs/default-source/publications/frac-code-list/frac_code_list 2018final.pdf?sfvrsn=6144b9a_2. Accessed 01 Feb 2019

IBGE (2017) Levantamento Sistemático da Produção Agrícola. https:// sidra.ibge.gov.br/tabela/6588\#resultado. Accessed 02 Feb 2019

Kurtz C, Menezes Júnior FOG, Higashikawa FS (2018) Fertilidade do solo, adubação e nutrição da cultura da cebola. Florianópolis: Epagri, p.104 (Epagri, Boletim Técnico 184)

Laviola C, Cannizzaro G, Conigliaro G, Burruano S (2006) Simple techniques for long-term storage of Plasmopara viticola. Phytopathol Mediterr 45:271-275

Mohibullah (1991): Studies on major disease of bulb vegetables (onion and garlic) in N.W.F.P. Province, Pakistan. Final Technical Report (October 1986 to September 1991). Agricultural Research institute Tarnab (Peshawar) NWFP Pakistan

Shaner G, Finney RE (1977) The effect of nitrogen fertilization on the expression of slow-mildewing resistance in Knox wheat. Phytopathology 67:1051-1056

Wordell Filho JA, Martins DA, Stadnik MJ (2007) Aplicação foliar de tratamentos para o controle do míldio e da podridão-de-escamas de bulbos de cebola. Hort Bras 25:544-549 